\title{
الاتجاهات الفكريه لعماره وزخارف مسجد صرحه
}

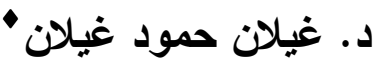

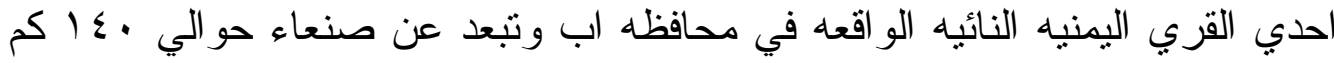

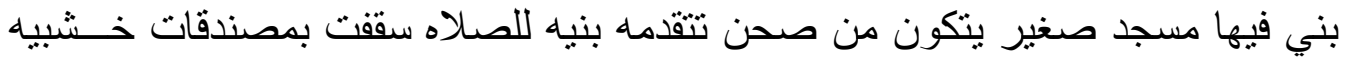

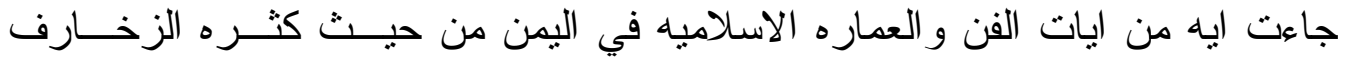
الهندسيه.

الهدف من هذا البحث هو توضيح اهم المفاهيم الفكريه التي اثرت علي الثي العمارهو والفنون

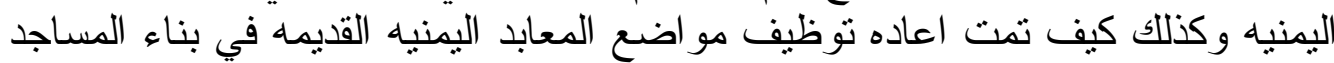

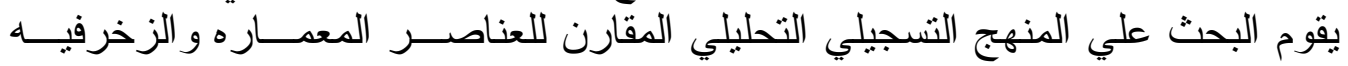

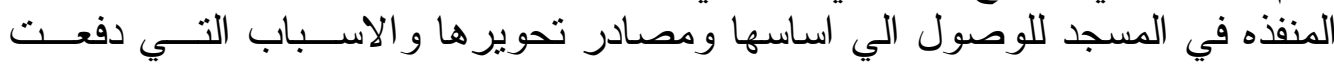

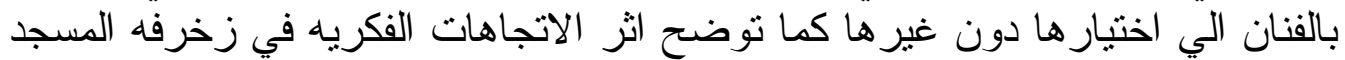

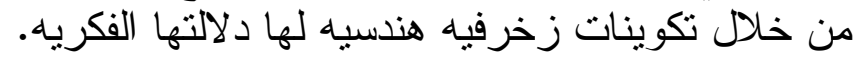

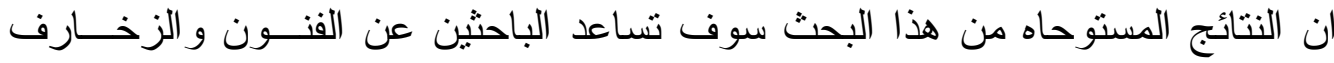
الاسلاميه في اليمن وكيف ساهم الفكر في تطور ها وازدهار هاء الئان

• عضو هيئة تدريس - قسم الاثار - جامعة صنعاء - ألقي ملذص البحث ولم يقدم البحث للنشر

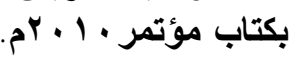

